Board of Governors of the Federal Reserve System

International Finance Discussion Papers

Number 708

August 2001

updated October 2002

\title{
A SIMPLE MEASURE OF THE INTENSITY OF CAPITAL CONTROLS
}

Hali J. Edison and Francis E. Warnock

forthcoming, Journal of Empirical Finance

NOTE: International Finance Discussion Papers are preliminary materials circulated to stimulate discussion and critical comment. References in publications to International Finance Discussion Papers (other than an acknowledgment that the writer has had access to unpublished material) should be cleared with the author or authors. Recent IFDPs are available on the Web at www.federalreserve.gov/pubs/ifdp/. 
Hali J. Edison and Francis E. Warnock ${ }^{*}$

\begin{abstract}
We propose a monthly measure of the intensity of capital controls across 29 emerging markets. Our measure, which is based on restrictions on foreign ownership of equities, provides information on the extent and evolution of financial liberalization. Using the measure, we show that a complete liberalization results in a much sharper decrease in the cost of capital than previously reported, but following a partial liberalization the cost of capital increases. Moreover, the more complete the liberalization is, the greater are the subsequent exchange rate appreciation and capital inflows.
\end{abstract}

JEL Classification: F3, G15

Keywords: emerging markets, international financial liberalization, openness, cost of capital

\footnotetext{
* The authors are, respectively, at the Research Department of the International Monetary Fund and in the International Finance Division of the Federal Reserve Board. We thank Assaf Razin for encouraging this research; Geert Bekaert (the editor), Jon Faust, Dennis Quinn, Charles Thomas, an anonymous referee, and participants in the Federal Reserve's IF Monday Workshop for helpful comments; Alka Banerjee of Standard and Poor's for help with the S\&P/IFC data; and Sara Holland for exceptional research assistance. The views in this paper are solely the responsibility of the authors and should not be interpreted as reflecting the views of the Board of Governors of the Federal Reserve System or the IMF, or of any other person associated with the Federal Reserve System or the IMF. email: $\underline{\text { HEdison@imf.org, frank.warnock@frb.gov }}$
} 


\section{Introduction}

There are few good measures of the degree of capital account liberalization, primarily because it is notoriously difficult to quantify. In the economics literature, most measures of capital controls are qualitative on/off indicators of the existence-but not the intensity — of rules or restrictions that inhibit capital flows. ${ }^{1}$ In the finance literature, the recent focus has been on dating financial liberalizations and treating them as one-time events or structural breaks, which presupposes that all liberalizations are similar in their intensity and speed (Bekaert and Harvey, 2000a; Henry, 2000a; Kim and Singal, 2000; Levine and Zervos, 1998). ${ }^{2}$ In our view both of these approaches can be refined.

The main purpose of this paper is to propose a measure that captures the intensity of capital controls and is available at a monthly frequency for a range of countries. The idea behind the measure is simple. For each emerging market country, Standard \& Poor's/International Finance Corporation (SP/IFC) computes two indices: a Global index (IFCG), designed to represent the market, and an Investable index (IFCI), designed to represent the portion of the market that is available to foreign investors. The ratio of the market capitalizations of a country's IFCI and IFCG indices provides a quantitative measure of the availability of the country's equities to foreigners, and one minus the ratio is a measure of the intensity of capital

${ }^{1}$ Many on/off measures build on the data published in the IMF'S Annual Report on Exchange Arrangements and Exchange Restrictions (AREAER). Quinn (1997) is the one study that uses the IMF data and attempts to score the intensity of controls. For thorough descriptions of this and other measures of capital controls, see Edison et al. (2002) and the survey of Eichengreen (2002).

${ }^{2}$ In this paper, as is customary in the international finance literature, we use the term financial liberalization when international financial liberalization (i.e., the opening of capital markets) would be more appropriate. For a discussion of the link between domestic and international financial liberalization, see Levine (2001). 
controls. ${ }^{3}$ The initial relaxation of controls displayed by our measure corresponds quite well with Bekaert and Harvey (2000a) liberalization dates, but our measure provides further information: It gives an explicit indication of the extent of the liberalization and its evolution over time, and shows that financial liberalizations can be gradual. ${ }^{4}$

A second purpose of this paper is to highlight the usefulness of our measure. Recently many emerging markets have opened their capital markets to foreign investors and several studies have examined the impact on cost of capital, volatility, beta, and correlation with world market returns, finding that the average effect of a liberalization—an average taken over liberalizations that differ greatly—is usually quite small. ${ }^{5}$ Using our measure we revisit these studies and show, for example, that the greater the liberalization is, the larger is the (i) decrease in the cost of capital (whereas after a minor opening the cost of capital increases), (ii) appreciation of the exchange rate, and (iii) increase in net capital inflows.

The data underlying our measure have been available for a number of years - Investable indices begin in December 1988 - but have not been widely utilized by researchers. A version of this measure has been used by Bekaert (1995) to form a measure of openness at one point in time, by Henry (2000a and 2000b) to date stock market liberalizations, and by Bachetta and van

${ }^{3}$ An annual version of the capital controls measure can be compiled using information from the annual Emerging Stock Markets Factbook, published until 1999 by the IFC and thereafter by Standard \& Poor's, who took over the maintenance and ownership of the IFC price indices. Our measure is available at www.federalreserve.gov/pubs/ifdp/2001/708/default.htm.

${ }^{4}$ Bekaert and Harvey $(1995,1997,2000 a)$ also allow for gradual integration, but do not use an explicit measure. (2000).

${ }^{5}$ See for example, Bekaert and Harvey (2000a), Henry (2000a), and Kim and Singal 
Wincoop (2000) to make the case that liberalizations appear to be gradual. However, it has never been put forth as a viable measure of capital controls that can be used in empirical work. ${ }^{6}$

The outline of our paper is as follows. Section 2 discusses salient features of the underlying indices and the methodology for computing our measure of foreign ownership restrictions. Section 3 presents the monthly restriction measure for 29 emerging markets economies and compares them with official liberalization dates from Bekaert and Harvey (2000a). Section 4 compares our measure with existing quantitative measures of capital controls and Section 5 revisits recent findings on the effects of liberalization. Section 6 gives concluding remarks and ideas for future research.

\section{Construction of the Capital Controls Measure}

In this section we discuss salient features of the published indices on which our measure of capital controls is based before describing the construction of the measure.

\subsection{The SP/IFC Indices $^{7}$}

For each emerging market country, SP/IFC computes two indices: a Global index, which is intended to represent the market, and an Investable index, which is a subset of the Global

${ }^{6}$ Recently, firm-level IFC data have been used by Chari and Henry (2001) and Bae, Chan, and $\mathrm{Ng}$ (2001) to examine characteristics of investable and non-investable firms.

${ }^{7}$ For a more complete description of the methodology behind the construction of the SP/IFC indices, see Standard \& Poor's (2000), from which the presentation in this subsection borrows heavily. 
index that represents the portion of the market available to foreigners. Each of these indices is discussed in turn.

\subsubsection{The SP/IFC Global Index}

All actively traded stocks of domestic companies are candidates for inclusion in a country's Global index. From the set of candidate stocks, a Global index is constructed to represent a target 60 to 75 percent of the country's total market capitalization and an industrial composition similar to that of the overall market. Once constituents are selected, their market capitalizations are adjusted downward for government ownership and, to avoid double counting, for cross-holdings of other index constituents. ${ }^{8}$ Some exceptions to the selection rules are made. For example, if a country's reported market capitalization includes a large amount of shares held by the government, 60 percent market coverage might not be achievable given the other criteria. Once a Global index is formed, stocks are typically added or deleted through an annual November review. Some events — such as a large initial public offerings (IPOs), delistings, lengthy trading suspensions, or disappearances through mergers - prompt immediate inclusion or removal outside of the annual review process.

\subsubsection{The SP/IFC Investable Index}

The Investable indices are comprised of a subset of the Global stocks that are available to foreign institutional investors and pass screens for minimum size (at least \$50 million in investable market capitalization) and liquidity (at least \$20 million in annual trading). Openness

${ }^{8}$ Adjustments for cross-holdings and government ownership were first implemented in November 1996. 
is determined first at the market level, based on the ability of foreign investors to buy and sell shares and repatriate capital, capital gains, and dividend income. Next, the extent of industry, corporate by-law, and corporate charter limitations on foreign ownership is determined. Based on the market's openness and the stock- and industry-specific limitations, an overall openness factor for the stock is calculated. ${ }^{9}$ This openness factor, or the stock's "investability", indicates the portion of the outstanding shares that foreigners may own, and is applied to the stock's market capitalization when calculating its weight in the Investable index.

As with the Global indices, some changes are made only at the annual review. ${ }^{10}$ For example, if a non-investable stock that is already in the Global index becomes available to foreign investors, it will only be added to the Investable index during the November rebalancing. Some events — such as a change in a market's openness, a large IPO, and a change in an Investable stock's investability—are dealt with as they occur, outside the annual review process.

\subsection{The Measure ${ }^{11}$}

It follows from the above discussion that one minus the ratio of the market capitalizations of a country's IFCI and IFCG indices is a measure of the intensity of its foreign ownership

${ }^{9}$ For example, at the end of 1996 Thailand had a general foreign ownership limit of 49 percent but a stricter 25 percent limit for financial firms. Thus, the openness factor for a typical Thai financial firm was 25 percent, whereas for most other Thai firms it was 49 percent.

${ }^{10}$ A substantial methodological change was implemented at the November 1996 rebalancing, when the IFC removed the effective market capitalization due to government ownership in order to better capture the free float. This lowered the market capitalization of many countries' Global indices, but the effect on Investable indices varied according to the severity of legal restrictions.

${ }^{11}$ Adjustments made to the underlying IFC data before forming our measure are discussed in the Appendix. 
restrictions. Specifically, a measure of the level of country $i$ 's foreign ownership restrictions at time $t, \mathrm{FOR}_{\mathrm{i}, \mathrm{t}}$, is

$$
F O R_{i, t}=1-\frac{M C_{i, t}^{I F C I}}{M C_{i, t}^{I F C G}}
$$

where MC is the market capitalization at time $t$ of country $i$ 's IFCI or IFCG indices. FOR can vary from zero to one, with zero representing a completely open market with no restrictions, and a value of one indicating that the market is completely closed. FOR as given by equation (1) is an indicator of the intensity of a country's capital controls at a point in time, and is therefore suitable for cross-sectional analysis, and over longer periods.

If a country has a uniform country-wide restriction on foreign ownership of its equities, changes in the measure given by equation (1) also provides an accurate indication of changes in restrictions. In the more general case, however, restrictions vary across stocks or sectors. In that case, asymmetric shocks to investable and non-investable stocks will lead to relative price changes and, hence, changes in the ratio of the market capitalizations. ${ }^{12}$ The noise in the monthly measure due to asymmetric shocks is easily dealt with by smoothing the measure using the investable and global price indices. Specifically, changes in the following smoothed measure are free of the effects of asymmetric price shocks:

${ }^{12}$ We thank Assaf Razin for bringing this point to our attention. An example is if banking sector stocks are in the IFCG but not available to foreigners, a pure banking sector shock would result in a change in the relative price of investable stocks and, therefore, a change in the relative market capitalizations. 
$F O R_{i, t}=1-\frac{M C_{i, t}^{I F C I} / P_{i, t}^{I F C I}}{M C_{i, t}^{I F C G} / P_{i, t}^{I F C G}}$

where $\mathrm{P}$ denotes the price indices. Since changes in $\mathrm{FOR}_{\mathrm{i}, \mathrm{t}}$ as given by equation (2) are free of relative price changes arising from asymmetric shocks, they give a more reasonable picture of month-to-month changes in capital controls. Thus, while equation (1) gives an indication of market-capitalization-weighted restrictions at any point in time, the first difference of the smoothed equation (2) is likely more appropriate for the analysis of monthly time series.

\section{Foreign Ownership Restrictions Since 1988}

This section presents our monthly measure of foreign ownership restrictions for 29 countries. In each figure, we show the measures given by equations (1) and (2) and, for comparison, we display official liberalization dates from Bekaert and Harvey (2000a) as vertical lines in the graphs. ${ }^{13}$

\subsection{Asia}

Our measures of foreign ownership restrictions for ten Asian countries - China, India, Indonesia, Korea, Malaysia, Pakistan, Philippines, Sri Lanka, Taiwan, and Thailand—are presented in Figures 1(a) - 1(j). A quick scan of the figures shows two important facts.

${ }^{13}$ Other liberalization dates include those in Henry (2000a) and the Bekaert and Harvey (2000a) dates of first country funds and first ADRs. 
First, restrictions in Asia were initially quite high—as we will show in Figure 2, much higher than restrictions in Latin America - but declined over the course of the 1990s in many countries. Second, each country is different in the timing, extent, and evolution of its liberalization process. Countries like Korea, Taiwan, Indonesia, and Thailand were relatively closed in the early 1990s, gradually relaxed foreign ownership restrictions over the course of the 1990s, then greatly relaxed restrictions during the 1997/98 Asian financial crisis. For these countries, the initial liberalization was just one relatively small step in the overall liberalization process. Other countries, like India and Sri Lanka, are no more open today than they were after their initial liberalizations. ${ }^{14}$

As noted, the dashed lines in the figures give the best indications of the extent of controls at a point in time, but are subject to frequent changes due to relative price shocks to investable and non-investable stocks. In contrast, the solid lines, which are adjusted for these asymmetric shocks, change only when restrictions change. For example, for the Philippines, shocks to the banking sector, which is largely unavailable to foreign investors, will result in changes in the ratio of the market capitalizations and thus movements in the dashed line. By using the IFCG and IFCI price indices to smooth out these changes, we get the solid line, which changes only when restrictions change.

Our measure can be further refined. For example, the sharp decrease in restrictions in China in November 1998 owes to the inclusion of "red chips" and Chinese stocks listed in Hong Kong ( $\mathrm{H}$-shares), all of which are to some extent investable. Because $\mathrm{H}$-shares were listed in

${ }^{14}$ See the time lines discussed in Bekaert and Harvey (2000b) and available on Campbell Harvey's web site, www.duke.edu/ charvey/Country risk/couindex.htm, for details on liberalizations in many emerging market countries. 
Hong Kong as early as 1993, a more accurate description of the evolution of foreign ownership restrictions in China would be a gradual relaxation from 1993 through 1998, rather than the sharp drop at the end of 1998. From 1999, the unadjusted measure is still the best indicator of the level of restrictions; the final point suggests the Chinese market is still about 60 percent closed.

\subsection{Latin America}

In contrast to Asian emerging markets, liberalizations in Latin America were much more extensive (Figure 2). It is quickly evident from the figures that the Latin American countries in our sample-Mexico, Argentina, Brazil, Chile, Colombia, Venezuela, and Peru-opened up to foreign investment far earlier and far more extensively than their Asian counterparts. Again, as with the Asian emerging markets, the $\mathrm{BH}$ liberalization dates for Latin America correspond quite well with the initial decrease in our restrictions measure. In Latin America, Argentina opened first - its equity market was almost completely open to foreign investment before our sample started — but others were not far behind, with Mexico opening its market by 1990 and Brazil and Peru following shortly thereafter.

There are two cases in Latin America that warrant further discussion. One is Chile, which shows a relaxation in the early 1990s, even though the country was at that time instituting capital controls, highlighting the fact that our measure is a narrow one. The controls Chile instituted in the mid-1990s were against short-term flows and favored longer-term flows such as 
equity purchases, hence there was no associated increase in our (equity) restrictions measure. ${ }^{15}$ The other interesting case is the liberalization process in Venezuela, which was slower to start and reversed to some extent in 1996 with the nationalization of the banking sector. Later that year, however, the banks were reprivatized and again available to foreign investors.

\subsection{Other Countries}

Figures 3 - 5 present our measure of foreign ownership restrictions for Eastern Europe, Europe, and Middle East/Africa. Not surprisingly, the measure for Eastern European countries (Figure 3) starts later in the sample period, with the earliest point being 1993. The most open of this group is Poland, which has been completely open since the beginning of the sample.

Interestingly, in Europe (Figure 4), until recently two countries, Greece and Portugal, had higher restrictions than in Latin America. ${ }^{16}$ In Middle East/Africa (Figure 5), South Africa has been quite open to foreign investment, but Jordan has relatively high restrictions, and the gradual relaxation of controls in Zimbabwe was partially reversed in 1998, leaving it with the most severe restrictions of this group. ${ }^{17}$

${ }^{15}$ See Edwards (2000) for a description of Chile's recent capital controls.

${ }^{16}$ The measure for Portugal ends in March 1999 when the IFC ceased to classify it as an emerging market.

${ }^{17}$ It might seem surprising that our measure indicates that South Africa has been open to foreign investment, given its dual exchange rate system. However, dual exchange rates affect foreigners' returns, not their ability to invest. 


\section{Comparison with Other Measures of Capital Controls}

Measures of capital account liberalization can be broadly grouped into two categories, rules based and outcome based, and then further differentiated into those that are on/off and those that provide some information on the intensity of controls. ${ }^{18}$ The on/off category includes most rules-based measures, such as those compiled using information from the International Monetary Fund's AREAER; see, for example, Grilli and Milesi-Ferretti (1995). Event studies also typically use rules-based on/off measures; see, for example, the official liberalization dates of Bekaert and Harvey (2000a) and Henry (2000a). Measures that provide information on the intensity of capital controls (or of a liberalization) are typically outcome based. ${ }^{19}$ Financial openness, calculated by expressing the Lane and Milesi-Ferretti (2001) estimates of cross-border portfolio and direct investment positions as a share of GDP, has been used in Edison et al. (2002b) and O'Donnell (2001) and, like measures of trade openness, is best thought of as a longrun outcome-based measure. That is, year-to-year changes in financial openness are likely driven more by changes in stock market valuations than by changes in capital account liberalization.

To compare our measure — which is essentially a market-capitalization-weighted rulesbased indicator - to existing measures, we must time-aggregate it to an annual frequency. Table 1 shows for nine emerging markets the means, standard deviations, and rank correlations of an

\footnotetext{
${ }^{18}$ For a comparison of rules-and outcome-based measures see IMF (2001) and Edison et al (2002).

${ }^{19}$ An exception is the rules-based measure of Quinn (1997), which attempts to capture the intensity of enforcement of controls through a careful reading of the narrative description in the AREAER.
} 
annual version of our measure and two measures that attempt to quantify the intensity with which the controls are imposed: the restrictions-based measure of Quinn (1997) and the outcome-based openness measure used in Edison et al. (2002b) and O’Donnell (2001).

There are a number of similarities between an annual version of our measure and the Quinn measure. First, the two measures are, as expected, strongly positively correlated for most countries, with the exceptions of Malaysia and Thailand. ${ }^{20}$ Second, for many of the countries the average level of restrictions is quite similar across the two measures; for example in the case of Mexico the means are 0.15 and 0.21 , respectively. Differences in the average levels of the two measures probably stem from differences in the spectrum (narrow or broad) of controls. For example, our measure suggests greater openness for Brazil and Chile than Quinn's measure, likely because both countries were relatively open to stock market investment but had substantial controls in other capital movement. In addition, for some of the Asian emerging markets, our measure shows greater restrictions, perhaps because these countries had stricter restrictions on equity investment than elsewhere in their financial accounts.

There are also a number of similarities between our measure and the openness measure. First, the two measures are, as expected given the definitions of the two indicators, strongly negatively correlated for six of the eight countries. ${ }^{21}$ The exceptions are, as with Quinn's measure, Malaysia and Thailand. Second, the levels of the means, while not directly

20 The negative correlations between our measure and the Quinn's measure for Malaysia is because Quinn's measure is constant except for one small change that happens to be in the opposite direction of a small change in our measure for that year. For Thailand, the timing of the liberalization is different than ours.

21 A higher value for an openness measure implies lower restrictions, so the correlation of an openness measure with our restrictions measure should be negative. 
comparable, do suggest that there is general agreement in the openness ranking of countries. For example, the measures are in agreement that Korea, Indonesia, and Brazil were relatively closed, and that Malaysia, Chile, and Mexico were relatively open.

\section{Empirical Applications}

The effects of financial liberalization on the cost of capital, returns, inflation, exchange rates, and capital flows have been analyzed in an event study framework by Bekaert and Harvey (2000a), Henry (2000a), and Kim and Singal (2000). However, some of the results—-for example, the small effect of liberalization on the cost of capital—have been surprising (Karolyi and Stulz, forthcoming). As described below, these previous investigations do not account for different types of liberalizations. Some liberalizations are partial while others are more complete; some are more or less one-time events, while others are more gradual. Pooling countries with different types of liberalizations could confound the effects of liberalization.

This section revisits these issues using our measure. The emphasis is on the effects on the cost of capital, the main variable in the Bekaert-Harvey study. For completeness the results for unconditional correlations and volatilities of returns, betas, and the levels and volatilities of exchange rates, inflation, and capital flows are also included. 


\subsection{Econometric Framework}

The regressions reported in this section all have the same general form, mimicking the methodology employed by Bekaert and Harvey (2000a). The generalized least squares regressions allow for panel specific heteroskedasticity and serial correlation. The sample consists of 14 countries (listed in the note to Table 2), begins with the first availability of data (December 1984 at the earliest, but varies by country and variable), and ends in December 1995 (the end date in the Bekaert-Harvey study, which is enough to capture the post-liberalization period in almost every country). ${ }^{22}$

We estimate two sets of regressions for each dependent variable, $Z$. The first is a baseline regression in which the explanatory variables are dummy variables that take the value of one in the PRE (from 36 to 7 months prior to the Bekaert-Harvey official liberalization date), DURING (from 6 months prior to 3 months past liberalization), POST (from 4 to 34 months after), or AFTER period (from 35 months after until the end of the sample), respectively. The baseline model is

$$
\begin{aligned}
& Z_{t}^{i}=\alpha^{i}+\beta_{1} P R E_{t}^{i}+\beta_{2} D_{U R I N G}{ }_{t}^{i}+\beta_{3} \text { POST }_{t}^{i}+\beta_{4} \text { AFTER }_{t}^{i}+\epsilon_{t}^{i} \\
& \epsilon_{t}^{i}=\rho^{i} \epsilon_{t-1}^{i}+u_{t}^{i}
\end{aligned}
$$

${ }^{22}$ We attempted to include all 20 countries in the Bekaert and Harvey (2000a) sample, but had to drop six for the following reasons: two countries for which the liberalization date was at the end of the sample period (Nigeria and Jordan) and four others (Greece, Portugal, Thailand, and Indonesia) for which the liberalization date was too far before the beginning date of our restrictions measure. 
Note that the regressions include country-specific constants, $\alpha^{\mathrm{i}}$, so the coefficients-which are constrained to be identical across countries-represent the effect relative to the period prior to PRE.

The second set of regressions takes into account the intensity of capital controls following liberalization. Specifically, to distinguish partial liberalizations from more complete ones the dummy variables in the POST and AFTER periods are replaced with $1-F O R$, a measure of the degree of openness. That is, in the second model equation (3) is replaced with

$$
Z_{t}^{i}=\alpha^{i}+\beta_{1} P R E_{t}^{i}+\beta_{2} \text { DURING }_{t}^{i}+\beta_{3}\left(1-\text { FOR }_{i}{ }^{t}\right) P O S T_{t}^{i}+\beta_{4}\left(1-\text { FOR }_{i}{ }^{t}\right) \text { AFTER }_{t}^{i}+\epsilon_{t}^{i}
$$

Note that we do not control for other variables that may affect our dependent variables. Hence, we view the results as illustrative and leave for further work a more complete analysis.

\subsection{The Effects of Financial Liberalization on the Cost of Capital}

When an emerging market liberalizes its capital markets - that is, when it evolves from a segmented market into one that is integrated with world markets - its cost of equity capital should fall. The effect documented in the event studies of Bekaert and Harvey (2000a) and Henry $(2000 \mathrm{a}, 2000 \mathrm{~b})$ is, however, surprisingly small. ${ }^{23}$ Figure 6 illustrates why. In each panel,

${ }^{23}$ In a current working paper, de Jong and de Roon (2001) examine the effects of timevarying integration on expected returns. 
the three periods analyzed in Bekaert and Harvey (2000a) are denoted: the pre-liberalization period, the "during" liberalization period, and the post-liberalization period. The graphs on the left side of the figure show that in three emerging markets whose initial liberalizations were partial — India, Korea, and Taiwan — the cost of capital tended to fall leading up to the initial liberalization but rose after the liberalization. In contrast, the graphs on right show that in three countries whose initial liberalizations were more extensive - Chile, Mexico, and Colombia - the cost of capital fell in the post-liberalization period. In pooled results, these conflicting effects confound the analysis.

Table 2 reproduces the main result from Bekaert and Harvey (2000a) and extends their analysis by incorporating information using our capital controls measure. The dependent variable is the IFC's dividend yield. The baseline results show a post-liberalization decrease in dividend yields of 42 basis points (the coefficient on POST is 0.42 less than the coefficient on PRE), which is comparable to the 31 basis point decrease reported in Bekaert and Harvey (2000a). ${ }^{24}$ In the regression using equation (3'), the coefficients on POST and AFTER represent the decrease (relative to the pre-PRE period) in dividend yields associated with a full liberalization. The results using the FOR measure confirm the patterns shown in Figure 6: A complete liberalization is associated with a 104 basis point decrease in dividend yields, more than two times greater than in the benchmark case, but a small ten percent liberalization, like that in Korea, results in an increase in dividend yields. ${ }^{25}$

Many factors—-such as macroeconomic influences and political risk—could explain the

${ }^{24}$ The difference in results owes to the slightly different sample.

25 The increase in dividend yields in this case follows because 10 percent of the POST coefficient is negative 0.14 , which is 24 basis points higher than the PRE coefficient. 
patterns we show in Figure 6 and Table 2. Bekaert and Harvey (2000a) analyze some of these, but the basic result of only a small decrease in the cost of capital carries through. In the simple case of no control variables, we have shown that large liberalizations are associated with sharp decreases in the cost of capital, while minor relaxations of controls can result in an increase.

\subsection{Further Results: Returns, Inflation, Exchange Rate, and Capital Inflows}

Tables 3-5 show the results of similar analyses for beta, the correlation of returns with global returns, and the level and unconditional volatility of returns, inflation, exchange rate changes, and capital inflows.

For returns (Table 3), results in the literature have been mixed and our results do not settle the issue. For example, Henry (2000a) documented a post-liberalization increase in returns, but Bekaert and Harvey (2000a) found no distinct pattern and Kim and Singal (2000) conclude that stock returns appear to increase then decrease after a liberalization. Our baseline regressions show an increase in returns from pre- to post-liberalization (and then a subsequent decrease), but our results with FOR do not point to a significant change in the post-liberalization period. ${ }^{26}$ For the volatility of returns, we do not find a significant liberalization effect, which is consistent with the literature. For correlations, our baseline results of a post-liberalization in correlations are in line with Bekaert and Harvey (2000a). However, when we take into account the degree of the liberalization, we do not find a significant effect on correlations; while for

${ }^{26}$ The coefficient on AFTER, the period from 35 months after the liberalization to the end of the sample, indicates a subsequent decrease in returns, as in Bekaert and Harvey (2000a) and Kim and Singal (2000). 
many countries the correlation with the world market increased after liberalization, for some countries that opened significantly—namely Mexico, Brazil, and Malaysia—the correlation fell. For beta, our results are generally insignificant.

Table 4 reports the effects of liberalization on exchange rates and inflation. Our results point to an appreciation of the exchange rate in an amount that varies according to the degree of liberalization: The exchange rate change associated with a complete opening is more than double the change brought on by a more minor (ten percent) opening. For exchange rate volatility, we find no significant effect. These exchange rate results contrast with Kim and Singal, who find that after a liberalization exchange rates continue to depreciate but at a slower rate and exchange rate volatility falls (at least for low inflation countries). Our inflation results are more consistent with the Kim and Singal results for low inflation countries. Inflation and its volatility fall after a liberalization, but the decrease is not statistically significant. In addition, the degree of liberalization appears to have little effect on the decrease in inflation, suggesting that other forces dominate.

Finally, the amount and (not surprisingly) the volatility of net portfolio equity inflows increase significantly following a liberalization (Table 5), and the increases depend on the extent of liberalization. For example, cumulative net inflows in the post-liberalization period for a country that fully opens its equity market is 1.9 percent of market capitalization per year (twelve times the coefficient value of 0.161 ); a ten percent opening attracts annual net inflows of only 0.2 percent of market capitalization over the same period. Moreover, the coefficient on POST in the regression with FOR is three and a half times that in the baseline regression, suggesting that not taking into account the degree of liberalization underestimates the effect on subsequent 
inflows. $^{27}$ The volatility of net equity inflows also increases post-liberalization and more so for complete liberalizations, but the magnitude (in standard deviations) is small relative to the mean inflow.

\section{Conclusion}

The existing economics and finance literatures on capital controls is short on high frequency measures of the intensity of controls across many countries. To address this need, we presented a measure based on restrictions on foreign ownership of equities. Our measurewhich can be thought of as an extension of the Bekaert and Harvey (2000a) liberalization dates that in addition provides information on the extent of the initial liberalization as well as its evolution over time - is roughly comparable to the lower frequency restrictions-based measure of Quinn (1997) and the openness measure used in Edison et al. (2002b) and O'Donnell (2001).

Armed with this measure, recent findings on the effects of financial liberalization can be revisited. For example, we provide evidence that the effects of liberalization on the cost of capital, the degree of exchange rate appreciation, and the amount of net capital inflows vary importantly with the extent of the liberalization.

These unconditional, univariate results should be seen as illustrative rather than definitive. More complete analyses would include various control factors. For example, we have used the measure in cross-sectional, multivariate analysis to show that capital controls do

${ }^{27}$ Bekaert, Harvey, and Lumsdaine (2002) report annual post-liberalization net inflows of 1.4 percent of market capitalization. 
not have an economically significant effect on home bias across a broad array of countries, but—consistent with the results in this paper—emerging markets can attract a significantly greater amount of foreign investment by reducing restrictions (Ahearne, Griever, and Warnock (forthcoming)). Controlling for global and local factors as well as cross-border listings, we show in another paper that the effect on capital flows of lowering restrictions is ambiguous and depends on whether the controls were binding (Edison and Warnock (2002)).

Future work can use this measure to reexamine the effects of liberalizations on economic growth, inflation, and other macroeconomic and financial variables. Steps are already being taken in these directions. For example, our measure is used in Bekaert, Harvey, and Lundblad (2001) to show that a full liberalization increases annual real per capita growth by 1.1 percent (and, therefore, that a ten percent opening has only a 0.1 percent annual growth effect) and in $\operatorname{IMF}(2002)$ to show that firms in more open economies are less leveraged and have lower ratios of short-term to total debt. 


\section{References}

Ahearne, A., W. Griever, and F. Warnock, forthcoming. "Information Costs and Home Bias: An Analysis of U.S. Holdings of Foreign Equities," Journal of International Economics.

Bacchetta, P., and E. van Wincoop, 2000. "Capital Flows to Emerging Markets: Liberalization, Overshooting, and Volatility," in Capital Flows and the Emerging Economies, ed. by S. Edwards, NBER and University of Chicago Press.

Bae, K.-H., K. Chan, and A. Ng, 2001. "Investability and Return Volatility in Emerging Equity Markets," unpublished paper (Hong Kong University).

Bekaert, G., 1995. "Market Integration and Investment Barriers in Emerging Equity Markets," World Bank Economic Review, 9(1): pp. 75-107.

Bekaert, G., and C.R. Harvey, 1995. "Time-Varying World Market Integration,” Journal of Finance, 50 (2): pp. 403-444. 1997. "Emerging Equity Market Volatility,” Journal of Financial Economics, 43: pp. $29-77$.

— 2000a. "Foreign Speculators and Emerging Equity Markets," Journal of Finance, 55(2): pp. 565-613.

— 2000b. "Capital Flows and the Behavior of Emerging Market Equity Returns," in Capital Inflows and the Emerging Economies, ed. by S. Edwards, NBER and University of Chicago Press.

Bekaert, G., C.R. Harvey, and R. Lumsdaine, 2002. "The Dynamics of Emerging Market Equity Flows," Journal of International Money and Finance, 21: 295-350.

Bekaert, G., C.R. Harvey, and C. Lundblad, 2001. "Does Financial Liberalization Spur Growth?" NBER Working Paper No. 8245 (Cambridge MA: National Bureau of Economic Research).

Chari, A., and P.B. Henry, 2001. "Stock Market Liberalizations and the Repricing of Systematic Risk," NBER Working Paper No. 8265, (Cambridge MA: National Bureau of Economic Research).

de Jong, F., and F. de Roon, 2001. "Time-Varying Market Integration and Expected Returns in Emerging Markets," unpublished paper (University of Amsterdam). 
Edison, H., M. Klein, L. Ricci, and T. Slok, 2002a. "Capital Account Liberalization and Economic Performance: A Review of the Literature,” IMF Working Paper 02/120 (Washington D.C: International Monetary Fund).

Edison, H., R. Levine, L. Ricci, and T. Slok, 2002b. "International Financial Integration and Economic Growth," Journal of International Money and Finance, 21: 749-776.

Edison, H., and F. Warnock, 2002. "Cross-Border Listings, Capital Controls, and Equity Flows to Emerging Markets," International Finance Discussion Paper, (Washington, DC: Board of Governors of the Federal Reserve System).

Edwards, S., 2000. "Capital Flows, Real Exchange Rates, and Capital Controls: Some Latin American Experiences," in Capital Inflows and the Emerging Economies, ed. by S. Edwards, NBER and University of Chicago Press.

Eichengreen, B., 2002. "Capital Account Liberalizations: What Do Cross-Country Studies Tell Us?" World Bank Economic Review.

Grilli, V., and G.M. Milesi-Ferretti, 1995. "Economic Effects and Structural Determinants of Capital Controls," IMF Staff Papers, 42: pp. 517:551.

Henry, P., 2000a. "Stock Market Liberalization, Economic Reform, and Emerging Market Equity Prices," Journal of Finance, 55(2): pp. 529-564.

—_ 2000b. "Do Stock Market Liberalizations Cause Investment Booms?" Journal of Financial Economics, 58: pp. 301-334.

International Monetary Fund, 2001. World Economic Outlook (Chapter 4).

International Monetary Fund, 2002. World Economic Outlook (Chapter 2).

Karolyi, A., and R. Stulz, forthcoming. "Are Financial Assets Priced Locally or Globally?" in Handbook of the Economics of Finance, ed. by G. Constantinedes, M. Harris, and R. Stulz.

Kim, E.H., and V. Singal, 2000. "Stock Market Openings: Experience of Emerging Economies" Journal of Business, 73(1): pp. 25-66.

Lane, P., and G.M. Milesi-Ferretti, 2001. "The External Wealth of Nations: Measures of Foreign Assets and Liabilities for Industrial and Developing Nations," Journal of International Economics 55: 263-294. 
Lewis, K., 1999. "Trying to Explain the Home Bias in Equities and Consumption,” Journal of Economic Literature, 37: pp. 571-608.

Levine, R., 2001. "International Financial Liberalization and Economic Growth," Review of International Economics, 9: 684-698.

Levine, R., and S. Zervos, 1998. “Capital Controls Liberalization and Stock Market Development," World Development, 26 (7): pp. 1169-1183.

O’Donnell, B., 2001. "Financial Openness and Economic Performance," (unpublished: Trinity College Dublin).

Quinn, D., 1997. "The Correlates of Changes in International Financial Regulation," American Political Science Review, 91: pp. 531-551.

Standard \& Poor's, 2000. “The S\&P Emerging Market Indices: Methodology, Definitions, and Practices." 


\section{Appendix: Adjustments to the Underlying Data}

We made the following types of adjustments to the IFC data when forming our measure:

- $\quad$ Extended IFCI data with zero market capitalization back to end-1988 for countries that were completely closed to foreign investment until some time during our sample period.

- Smoothed over temporary IFC adjustments that appear to be unrelated to changes in capital controls. Example: Ten Argentinian stocks were removed from the IFCI in January 1993, probably because of reduced liquidity, and reinstated in January 1994.

- $\quad$ Redistributed changes in investability when a country changes its capital controls but the IFC delays adjusting the IFCI index. Examples: The May 1997 change in Korean foreign ownership limits (included in the IFCI in November 1997) and the January 1992 implementation of Chilean Law DL600 (included in the IFCI in January 1996).

- Used information not included in the country-level indices where appropriate. Example: Malaysia had a zero weight in the worldwide Investable index when it instituted strict capital controls in late 1998, but this was not reflected in the Malaysian IFCI.

- $\quad$ Smoothed over one-period spikes in investability.

The following is a complete list of adjustments made:

Argentina $\quad$ Smoothed over a 1993:1 to 1993:12 increase in FOR that was due to firms being dropped from the IFCI and subsequently reinstated.

Brazil In January 1993, the IFC added a number of voting common stocks. Such stocks, which were available to investors prior to this date, have full weight in the IFCG but reduced weight in the IFCI (in some cases a zero weighting) because of Brazil's foreign ownership limits on this class of shares. Thus, their inclusion in January 1993 resulted in an increase in FOR that had nothing to do with changes in capital controls. Furthermore, the investable weight for some of these voting common stocks was increased in January 1994. We eliminated the changes in FOR caused by the inclusion of these shares by extending the 1994:01 value of FOR back to January 1992 and adding 0.06 to FOR in the 1991:06 to 1991:12 period.

Chile In January 1996, IFC decided to apply DL600, not LAN18657 as previously, to determine foreign limits in the IFCI index, and the limits increased from $25 \%$ to $100 \%$. We moved the change back to when DL600 was actually implemented, January 1992.

Colombia Eliminated effects of multiple changes in weights of Banco Santander and Candenalco, which reduces 1992:01 decrease in FOR and thus eliminates 1993:01 increase. 
Czech Rep. $\quad$ Eliminated a 1998:8-1998:9 spike in FOR that owed entirely to new issuance of a restricted share. India $\quad$ Set MC $\mathrm{MC}^{\mathrm{IFI}}$ equal to zero for December 1988 - October 1992.

Indonesia Eliminated increases in January and September 2000 that were due to new share issuances by restricted firms.

Korea $\quad$ Set MC $\quad$ IFCI equal to zero for December 1988 - December 1991.

Distributed half the November 1997 increase in $\mathrm{MC}^{\mathrm{IFCI}}$ to May 1997.

Eliminated 2000:11-2000:12 increase that owed to the addition of two restricted stocks.

Malaysia $\quad$ Made FOR flat for 1990:1 to 1993:12. Otherwise it would move down (stocks with restrictions dropped) and then up (some restricted stocks added) without changes in capital controls. Set $\mathrm{MC}^{\mathrm{IFCI}}$ equal to zero for October 1998 - October 1999.

Mexico Eliminated slight increase in FOR in 1994:1 (due to the inclusion of some restricted shares) by increasing slightly 1993:1 - 1993:12.

Peru Eliminated effects of multiple changes in the investability of Buenaventura between 1998:11 and 1999:10, which eliminates a 1998:11 increase in FOR.

Sri Lanka Eliminated a large temporary decrease in FOR in 1995 that was due to a temporary (and later reversed) increase in some investable weights.

Taiwan $\quad$ Set MC ${ }^{\mathrm{IFCI}}$ equal to zero for December 1988 - December 1990.

Zimbabwe $\quad$ Set MC ${ }^{\mathrm{IFCI}}$ equal to zero for December 1988 - May 1993.

Smoothing of spikes:*

Argentina 1990:12(1990:11), 1991:12(1991:11); Brazil 1990:12(1990:11), 1996:4(1996:5); Chile 1990:12(1990:11); China 1997:11(1997:12), 1998:11(1998:12); Czech Republic 1995:7(1995:8), 1998:11(1998:12); Hungary

1995:12(1995:11), 1996:10 (1996:9); India 1992:11(1993:1), 1992:12(1993:1); Indonesia

1990:12(1990:11),1991:12(1991:11), 1996:1(1995:12);Greece 1990:12(1990:11); Mexico 1990:12(1990:11),

1991:12(1991:11), 1992:4(1992:3),1998:11(1998:12); Peru 1993:12 (1994:1); Slovakia 1998:7(1998:6); Thailand

1990:12(1990:11), 1991:12(1991:11); Turkey 1990:12(1990:11); Venezuela

1990:12(1991:1),1991:3(1991:2),1991:4(1991:2)

*Listed are dates for which data were changed, with dates from which values were taken in parentheses. 
Table 1. Capital Controls Measures: Means, Standard Deviations, and Correlations

\begin{tabular}{|c|c|c|c|}
\hline & Openness & Quinn & $\begin{array}{l}\text { Edison - } \\
\text { Warnock }\end{array}$ \\
\hline Mexico & $\begin{array}{c}0.24 \\
(0.08) \\
\\
\mathbf{- 0 . 8 8}\end{array}$ & $\begin{array}{c}0.15 \\
(0.02) \\
\\
\mathbf{0 . 7 5}\end{array}$ & $\begin{array}{c}0.21 \\
(0.22)\end{array}$ \\
\hline Argentina & $\begin{array}{c}0.16 \\
(0.07) \\
\\
\mathbf{- 0 . 9 5}\end{array}$ & $\begin{array}{c}0.18 \\
(0.13) \\
\\
\mathbf{0 . 9 8}\end{array}$ & $\begin{array}{c}0.05 \\
(0.06)\end{array}$ \\
\hline Brazil & $\begin{array}{c}0.14 \\
(0.04) \\
\\
\mathbf{- 0 . 8 1}\end{array}$ & $\begin{array}{c}0.72 \\
(0.02) \\
\\
\mathbf{0 . 7 8}\end{array}$ & $\begin{array}{c}0.45 \\
(0.24)\end{array}$ \\
\hline Chile & $\begin{array}{c}0.33 \\
(0.13) \\
\\
\mathbf{- 0 . 9 0}\end{array}$ & $\begin{array}{c}0.38 \\
(0.07) \\
\\
\mathbf{0 . 9 5}\end{array}$ & $\begin{array}{c}0.28 \\
(0.41)\end{array}$ \\
\hline Korea & $\begin{array}{c}0.09 \\
(0.04) \\
\\
\mathbf{- 0 . 5 7}\end{array}$ & $\begin{array}{c}0.40 \\
(0.02) \\
\\
\mathbf{1 . 0 0}\end{array}$ & $\begin{array}{c}0.90 \\
(0.11)\end{array}$ \\
\hline Indonesia & $\begin{array}{c}0.08 \\
(0.04) \\
\\
\mathbf{- 0 . 8 6}\end{array}$ & $\begin{array}{c}0.27 \\
(0.02) \\
\\
\mathbf{0 . 8 9}\end{array}$ & $\begin{array}{c}0.53 \\
(0.12)\end{array}$ \\
\hline Malaysia & $\begin{array}{c}0.50 \\
(0.04) \\
\\
\mathbf{- 0 . 0 3}\end{array}$ & $\begin{array}{c}0.23 \\
(0.02) \\
\\
\mathbf{- 1 . 0 0}\end{array}$ & $\begin{array}{c}0.22 \\
(0.07)\end{array}$ \\
\hline Philippines & na & $\begin{array}{c}0.37 \\
(0.22) \\
\\
\mathbf{0 . 5 9}\end{array}$ & $\begin{array}{c}0.53 \\
(0.04)\end{array}$ \\
\hline Thailand & $\begin{array}{c}0.21 \\
(0.04) \\
\mathbf{0 . 1 3}\end{array}$ & $\begin{array}{c}0.31 \\
(0.15) \\
\\
\mathbf{- 0 . 4 7}\end{array}$ & $\begin{array}{c}0.70 \\
(0.03)\end{array}$ \\
\hline
\end{tabular}

Notes. This tables compares three measures over the period 1989 - 1997: an annualized version of our measure from Equation (1), an annual openness measure derived from the data of Lane and Milesi-Ferretti (2001), and the Quinn (1997) annual measure rescaled to be between zero and one. (The comparisons for Indonesia start in 1990.) In each cell, the first line gives the mean, the second line the standard deviation, and the third line (in bold) the rank correlation with our measure. 
Table 2: The Impact of Liberalization Dividend Yields

\begin{tabular}{|l|c|c|c|c|c|}
\hline & PRE & DURING & POST & AFTER & WALD \\
\hline Baseline & -0.513 & -0.773 & -0.932 & -1.125 & 10.18 \\
& $(.107)$ & $(.142)$ & $(.159)$ & $(.176)$ & {$[.001]$} \\
\hline \multirow{2}{*}{ with FOR } & -0.381 & -.499 & -1.425 & -1.707 & 17.61 \\
& $(.092)$ & $(.109)$ & $(.268)$ & $(.300)$ & {$[.000]$} \\
\hline
\end{tabular}

Notes. Regressions allow for panel specific heteroskedasticity and serial correlation and mirror those in Bekaert and Harvey (2000a), Table 3 Panel D, as much as possible. Dependent variable is the IFC's dividend yield, adjusted to omit zero entries as in Bekaert and Harvey (2000a). In the baseline regression, which corresponds to equation (3), the explanatory variables are dummy variables that take the value of one 36 to seven months prior to the Bekaert-Harvey official liberalization date (PRE), six months prior to 3 months after liberalization (DURING), four months after to 34 months after liberalization (POST), or from 35 months after liberalization until the end of the sample (AFTER). The regressions with FOR correspond to equation (3') and are identical to the baseline regressions, except the POST and AFTER variables take the value of 1 - FOR. Country-specific constants are also included but not reported, so the coefficients represent the effect relative to the period prior to PRE; in the case of the regression with FOR, the effects in POST and AFTER are of a complete liberalization. The sample period is from the first availability of dividend yield data (December 1984 at the earliest, but varies by country) to December 1995 (the end date in the Bekaert-Harvey study). Fourteen of the $20 \mathrm{BH}$ countries are included (Argentina, Brazil, Chile, Colombia, India, Korea, Malaysia, Mexico, Pakistan, Philippines, Taiwan, Turkey, Venezuela, and Zimbabwe); see text footnote 22 for reasons $6 \mathrm{BH}$ countries were dropped. P-values of a Wald test on the difference between the PRE and POST liberalization coefficients are in brackets. Standard errors are in parentheses; all coefficients are significant at the one percent level. 
Table 3: The Impact of Liberalization on Returns

\begin{tabular}{|c|c|c|c|c|c|c|}
\hline & & PRE & DURING & POST & AFTER & WALD \\
\hline \multirow[t]{2}{*}{ Levels } & Baseline & $\begin{array}{c}-2.349 \\
(.781)\end{array}$ & $\begin{array}{c}-0.793 \\
(1.139)\end{array}$ & $\begin{array}{c}-0.516 \\
(.798)\end{array}$ & $\begin{array}{c}-2.724 \\
(.965)\end{array}$ & $\begin{array}{c}5.06 \\
{[.024]}\end{array}$ \\
\hline & with FOR & $\begin{array}{r}-2.349 \\
(.753)\end{array}$ & $\begin{array}{c}-0.777 \\
(1.120)\end{array}$ & $\begin{array}{c}-1.629 \\
(1.522)\end{array}$ & $\begin{array}{c}-4.041 \\
(1.509)\end{array}$ & $\begin{array}{c}0.27 \\
{[.606]}\end{array}$ \\
\hline \multirow[t]{2}{*}{ Volatility } & Baseline & $\begin{array}{l}0.076 \\
(.131)\end{array}$ & $\begin{array}{r}-0.195 \\
(.180)\end{array}$ & $\begin{array}{c}-0.132 \\
(.209)\end{array}$ & $\begin{array}{c}-0.106 \\
(.236)\end{array}$ & $\begin{array}{c}1.49 \\
{[.222]}\end{array}$ \\
\hline & with FOR & $\begin{array}{l}0.085 \\
(.116)\end{array}$ & $\begin{array}{c}-0.183 \\
(.143)\end{array}$ & $\begin{array}{r}-0.247 \\
(.297)\end{array}$ & $\begin{array}{c}-0.238 \\
(.354)\end{array}$ & $\begin{array}{c}1.51 \\
{[.218]}\end{array}$ \\
\hline \multirow[t]{2}{*}{ Beta } & Baseline & $\begin{array}{r}-0.007 \\
(.017)\end{array}$ & $\begin{array}{c}-0.004 \\
(.022)\end{array}$ & $\begin{array}{l}0.003 \\
(.025)\end{array}$ & $\begin{array}{l}0.019 \\
(.027)\end{array}$ & $\begin{array}{c}0.25 \\
{[.614]}\end{array}$ \\
\hline & with FOR & $\begin{array}{r}-0.011 \\
(.015)\end{array}$ & $\begin{array}{r}-0.010 \\
(.018)\end{array}$ & $\begin{array}{r}-0.012 \\
(.044)\end{array}$ & $\begin{array}{l}0.006 \\
(.048)\end{array}$ & $\begin{array}{c}0.00 \\
{[.977]}\end{array}$ \\
\hline \multirow[t]{2}{*}{ Correlation } & Baseline & $\begin{array}{r}-0.002 \\
(.012)\end{array}$ & $\begin{array}{l}0.019 \\
(.016)\end{array}$ & $\begin{array}{l}0.034 \\
(.018)\end{array}$ & $\begin{array}{l}0.030 \\
(.020)\end{array}$ & $\begin{array}{c}6.16 \\
{[.013]}\end{array}$ \\
\hline & with FOR & $\begin{array}{r}-0.014 \\
(.010)\end{array}$ & $\begin{array}{c}-0.004 \\
(.012)\end{array}$ & $\begin{array}{l}0.001 \\
(.027)\end{array}$ & $\begin{array}{l}0.002 \\
(.031)\end{array}$ & $\begin{array}{c}0.36 \\
{[.549]}\end{array}$ \\
\hline
\end{tabular}

Notes. Regressions allow for panel specific heteroskedasticity and serial correlation and are tailored after those in Bekaert and Harvey (2000a), Table 3 Panel D. Dependent variables, in the first column, are based on returns using the IFC's price in US dollars. Volatility and correlation are computed from months $t$ to $t+36$. P-values of a Wald test on the difference between the PRE and POST liberalization coefficients are in brackets. Standard errors are in parentheses. See notes to Table 2 for further details on the regressions. 
Table 4: The Impact of Liberalization on Exchange Rates and Inflation

\begin{tabular}{|c|c|c|c|c|c|c|}
\hline & & PRE & DURING & POST & AFTER & WALD \\
\hline \multirow[t]{3}{*}{$\begin{array}{l}\text { Exchange Rate } \\
\text { Changes }\end{array}$} & Baseline & $\begin{array}{l}-0.381 \\
(.191)\end{array}$ & $\begin{array}{l}-0.084 \\
(.263)\end{array}$ & $\begin{array}{l}0.176 \\
(.205)\end{array}$ & $\begin{array}{l}0.592 \\
(.254)\end{array}$ & $\begin{array}{c}7.22 \\
{[.007]}\end{array}$ \\
\hline & with FOR & $\begin{array}{l}-0.352 \\
(.175)\end{array}$ & $\begin{array}{l}-0.086 \\
(.242)\end{array}$ & $\begin{array}{l}0.635 \\
(.392)\end{array}$ & $\begin{array}{l}1.165 \\
(.405)\end{array}$ & $\begin{array}{c}7.23 \\
{[.007]}\end{array}$ \\
\hline & Baseline & $\begin{array}{l}-0.006 \\
(.047)\end{array}$ & $\begin{array}{l}-0.026 \\
(.064)\end{array}$ & $\begin{array}{l}-0.007 \\
(.071)\end{array}$ & $\begin{array}{l}-0.001 \\
(.074)\end{array}$ & $\begin{array}{c}0.00 \\
{[.989]}\end{array}$ \\
\hline Volatility & with FOR & $\begin{array}{l}0.012 \\
(.043)\end{array}$ & $\begin{array}{l}0.007 \\
(.055)\end{array}$ & $\begin{array}{l}0.074 \\
(.117)\end{array}$ & $\begin{array}{l}0.069 \\
(.127)\end{array}$ & $\begin{array}{c}0.37 \\
{[.542]}\end{array}$ \\
\hline \multirow{2}{*}{$\begin{array}{l}\text { Inflation } \\
\qquad \text { Levels }\end{array}$} & Baseline & $\begin{array}{l}0.359 \\
(.183)\end{array}$ & $\begin{array}{l}0.620 \\
(.239)\end{array}$ & $\begin{array}{l}0.199 \\
(.218)\end{array}$ & $\begin{array}{l}0.386 \\
(.283)\end{array}$ & $\begin{array}{c}0.57 \\
{[.450]}\end{array}$ \\
\hline & with FOR & $\begin{array}{l}0.285 \\
(.169)\end{array}$ & $\begin{array}{l}0.488 \\
(.216)\end{array}$ & $\begin{array}{l}-0.016 \\
(.382)\end{array}$ & $\begin{array}{l}0.324 \\
(.453)\end{array}$ & $\begin{array}{c}0.70 \\
{[.403]}\end{array}$ \\
\hline \multirow{2}{*}{ Volatility } & Baseline & $\begin{array}{l}-0.002 \\
(.011)\end{array}$ & $\begin{array}{l}-0.008 \\
(.015)\end{array}$ & $\begin{array}{l}-0.009 \\
(.017)\end{array}$ & $\begin{array}{l}-0.007 \\
(.019)\end{array}$ & $\begin{array}{c}0.24 \\
{[.626]}\end{array}$ \\
\hline & with FOR & $\begin{array}{l}-0.002 \\
(.010)\end{array}$ & $\begin{array}{l}-0.008 \\
(.012)\end{array}$ & $\begin{array}{l}-0.016 \\
(.035)\end{array}$ & $\begin{array}{l}-0.008 \\
(.041)\end{array}$ & $\begin{array}{c}0.20 \\
{[.651]}\end{array}$ \\
\hline
\end{tabular}

Notes. Regressions allow for panel specific heteroskedasticity and serial correlation and are tailored after those in Bekaert and Harvey (2000a), Table 3 Panel D. Dependent variables are in the first column. Exchange rate changes are based on monthly exchange rates for each country taken from line AH of International Financial Statistics, using the U.S. dollar as the reference currency. Inflation is based on monthly changes in the consumer price index for each country taken from line 64 of International Financial Statistics. IFS data are not available for Taiwan. Volatilities are computed from months $t$ to $t+36$. Pvalues of a Wald test on the difference between the PRE and POST liberalization coefficients are in brackets. Standard errors are in parentheses. See notes to Table 2 for further details on the regressions. 
Table 5: The Impact of Liberalizations on Net Flows as a Percent of Market Capitalization

\begin{tabular}{|c|c|c|c|c|c|c|}
\hline & & PRE & DURING & POST & AFTER & WALD \\
\hline \multirow[t]{2}{*}{ Levels } & Baseline & $\begin{array}{l}0.003 \\
(.008)\end{array}$ & $\begin{array}{l}0.007 \\
(.012)\end{array}$ & $\begin{array}{l}0.045 \\
(.009)\end{array}$ & $\begin{array}{l}0.059 \\
(.013)\end{array}$ & $\begin{array}{l}20.96 \\
{[.000]}\end{array}$ \\
\hline & with FOR & $\begin{array}{l}0.001 \\
(.003)\end{array}$ & $\begin{array}{r}-0.001 \\
(.005)\end{array}$ & $\begin{array}{l}0.161 \\
(.016)\end{array}$ & $\begin{array}{l}0.137 \\
(.021)\end{array}$ & $\begin{array}{l}110.69 \\
{[.000]}\end{array}$ \\
\hline \multirow[t]{2}{*}{ Volatility } & Baseline & $\begin{array}{c}0.0004 \\
(.001)\end{array}$ & $\begin{array}{l}0.001 \\
(.002)\end{array}$ & $\begin{array}{l}0.003 \\
(.002)\end{array}$ & $\begin{array}{l}0.004 \\
(.003)\end{array}$ & $\begin{array}{c}2.20 \\
{[.138]}\end{array}$ \\
\hline & with FOR & $\begin{array}{c}-0.0003 \\
(.001)\end{array}$ & $\begin{array}{l}0.001 \\
(.001)\end{array}$ & $\begin{array}{l}0.014 \\
(.005)\end{array}$ & $\begin{array}{l}0.016 \\
(.006)\end{array}$ & $\begin{array}{c}8.77 \\
{[.003]}\end{array}$ \\
\hline
\end{tabular}

Notes. Regressions allow for panel specific heteroskedasticity and serial correlation and are tailored after those in Bekaert and Harvey (2000a), Table 3 Panel D. Dependent variables, in the first column, are based on monthly net capital flows from the US as a percent of market capitalization. Capital flows data is available from the U.S. Treasury Department's Treasury International Capital (TIC) System. TIC data are not available for Zimbabwe. Market capitalization in U.S. dollars comes from the IFC. Volatilities are computed from months $t$ to $t+36$. P-values of a Wald test on the difference between the PRE and POST liberalization coefficients are in brackets. Standard errors are in parentheses. See notes to Table 2 for further details on the regressions. 
Figure 1. Foreign Ownership Restrictions, Emerging Asia. Solid lines, which correspond to equation (2), are corrected for relative price changes. Dashed lines correspond to equation (1). Vertical lines indicate Bekaert and Harvey (2000a) liberalization dates, which are not available for China and Sri Lanka and were prior to 1989 for Thailand and Malaysia.
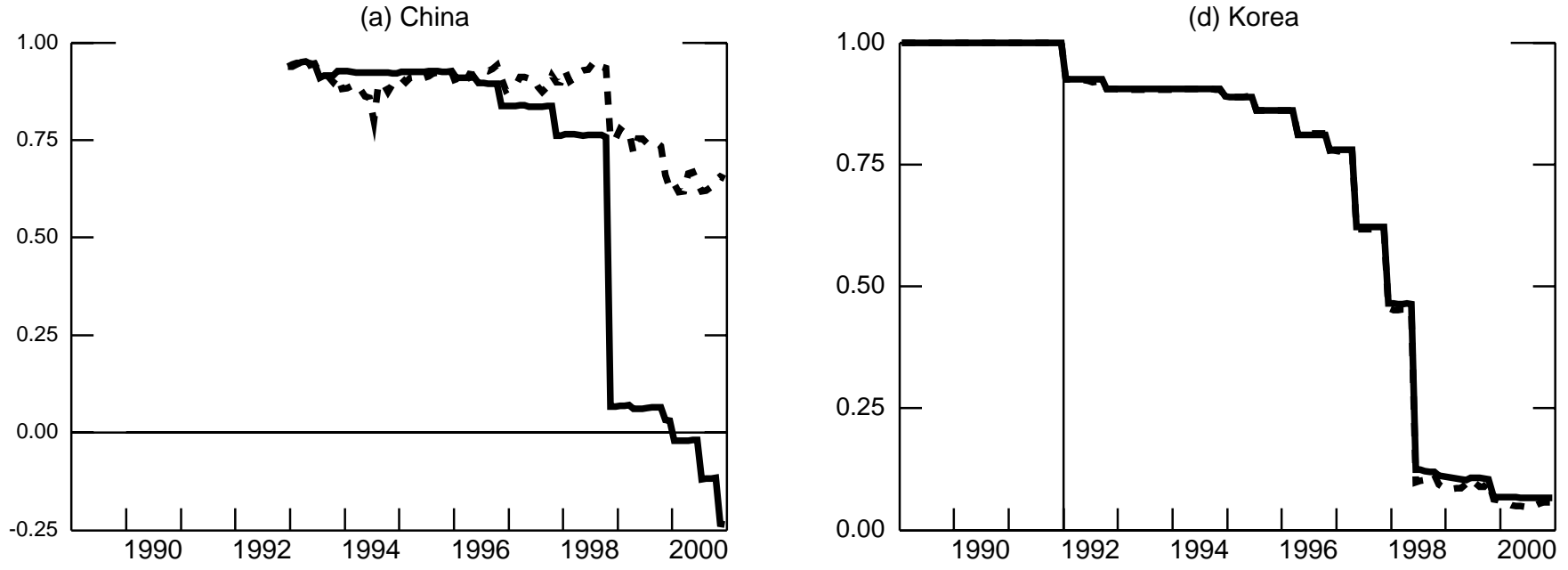

(b) India

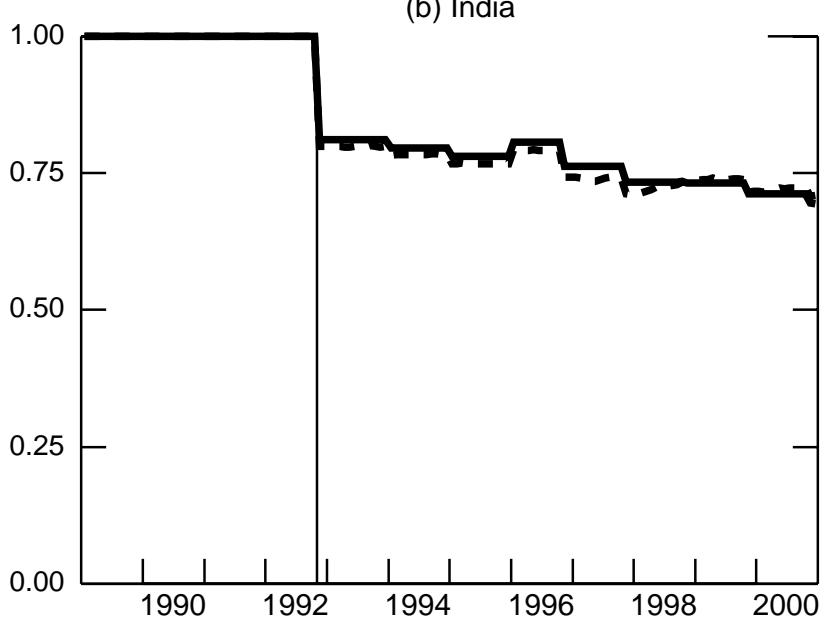

(c) Indonesia

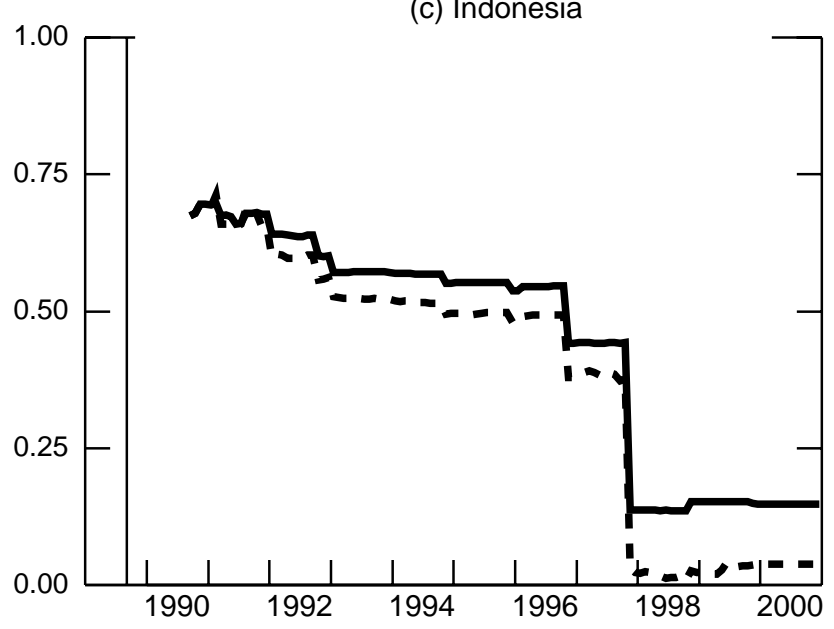

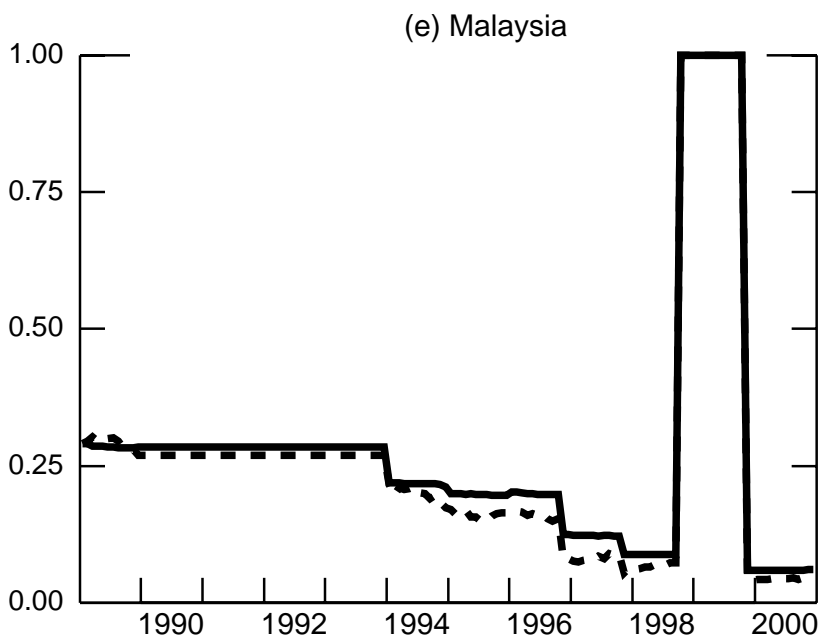

(f) Pakistan

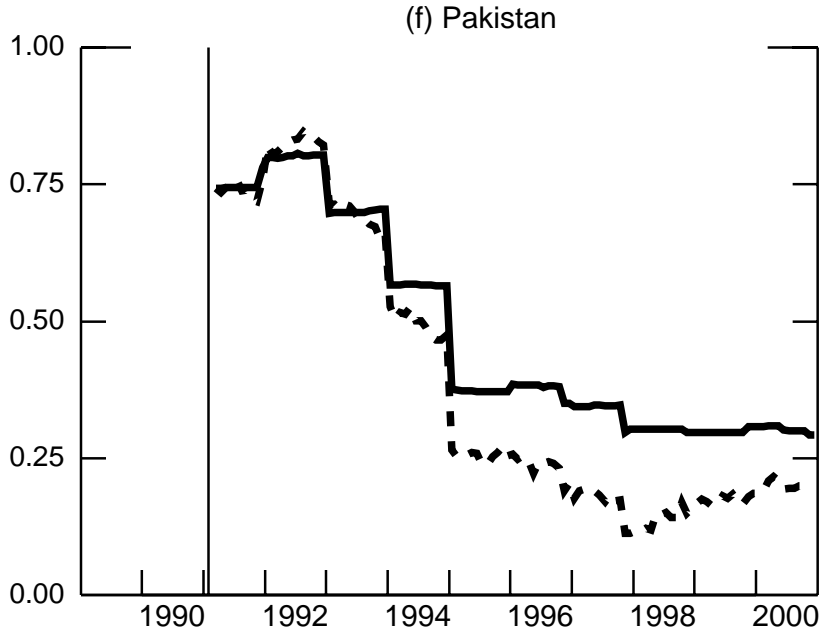


Figure 1. Foreign Ownership Restrictions, Emerging Asia (continued).
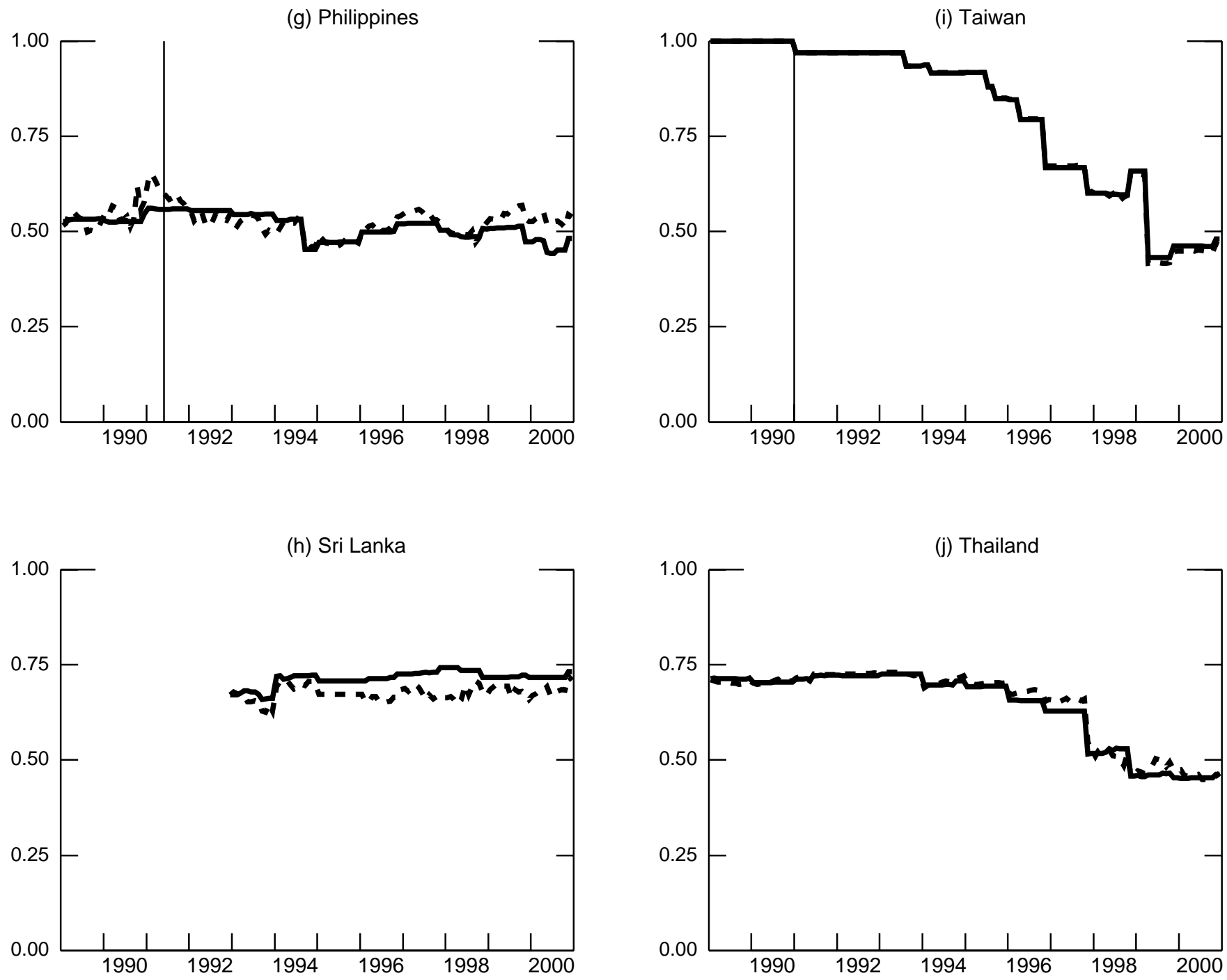
Figure 2. Foreign Ownership Restrictions, Latin America. See Figure 1 for description. Bekaert and Harvey (2000a) liberalization dates are not available for Peru.
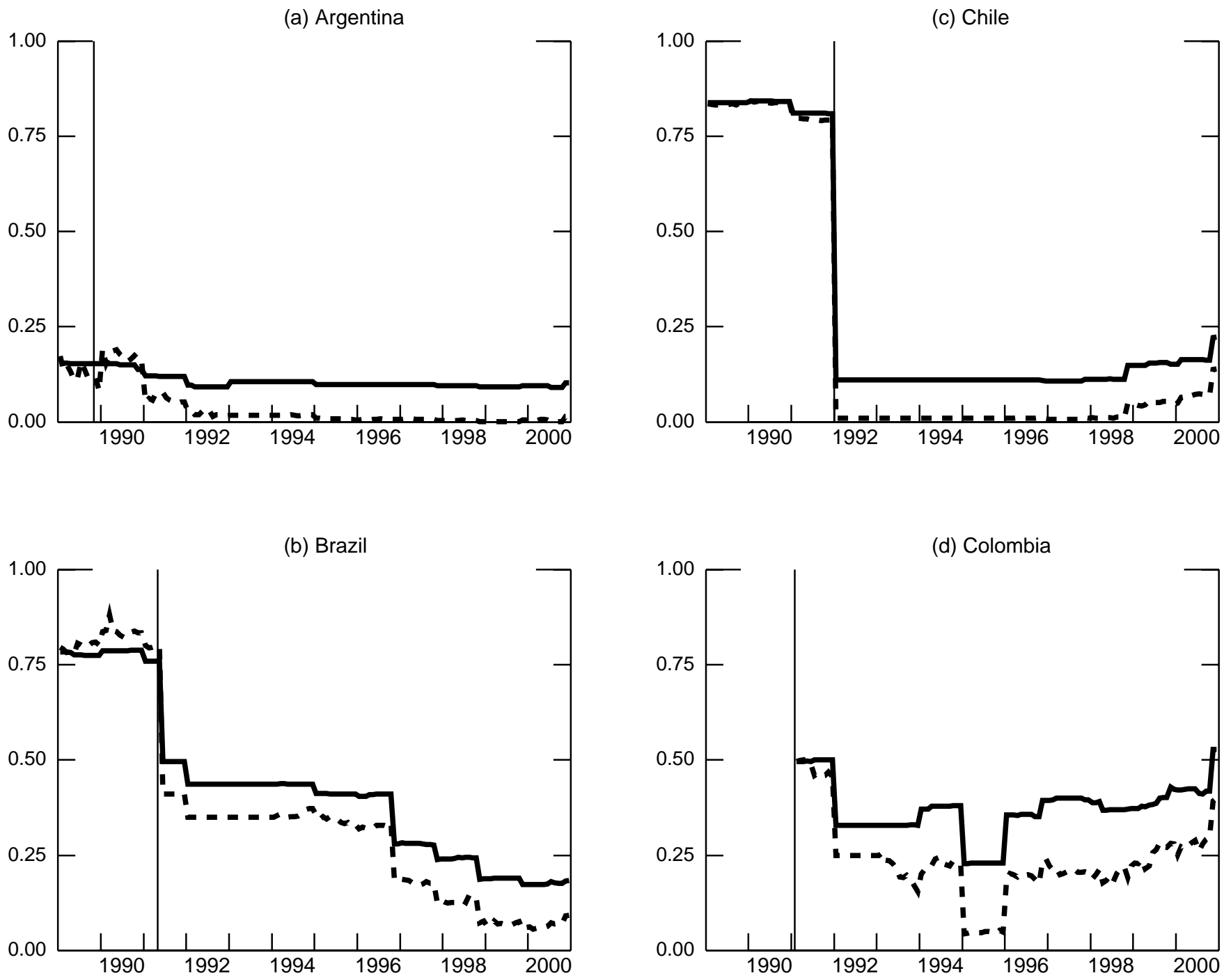
Figure 2. Foreign Ownership Restrictions, Latin America (continued).
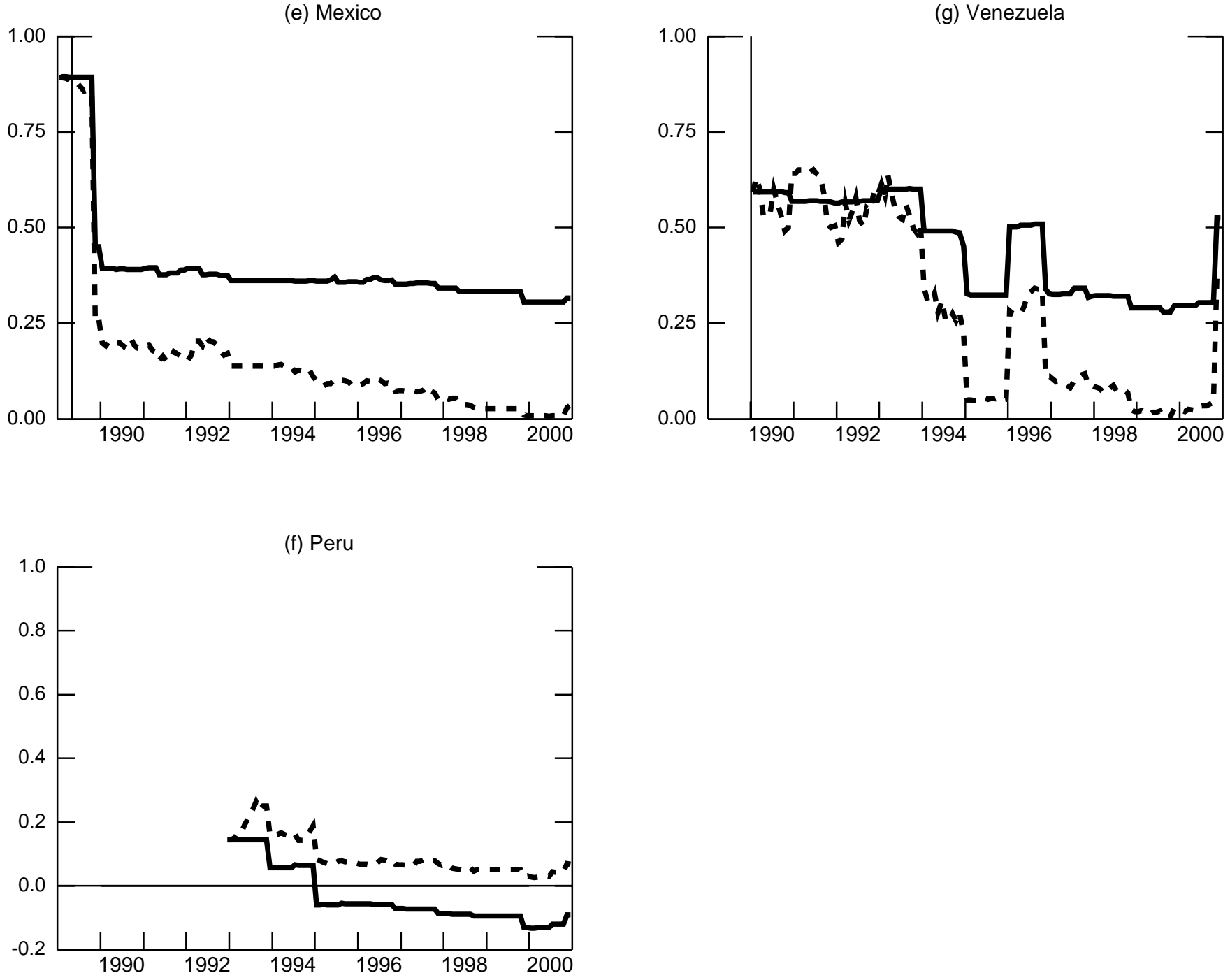
Figure 3. Foreign Ownership Restrictions, Eastern Europe. See Figure 1 for description. Bekaert and Harvey (2000a) liberalization dates are not available for Eastern Europe.
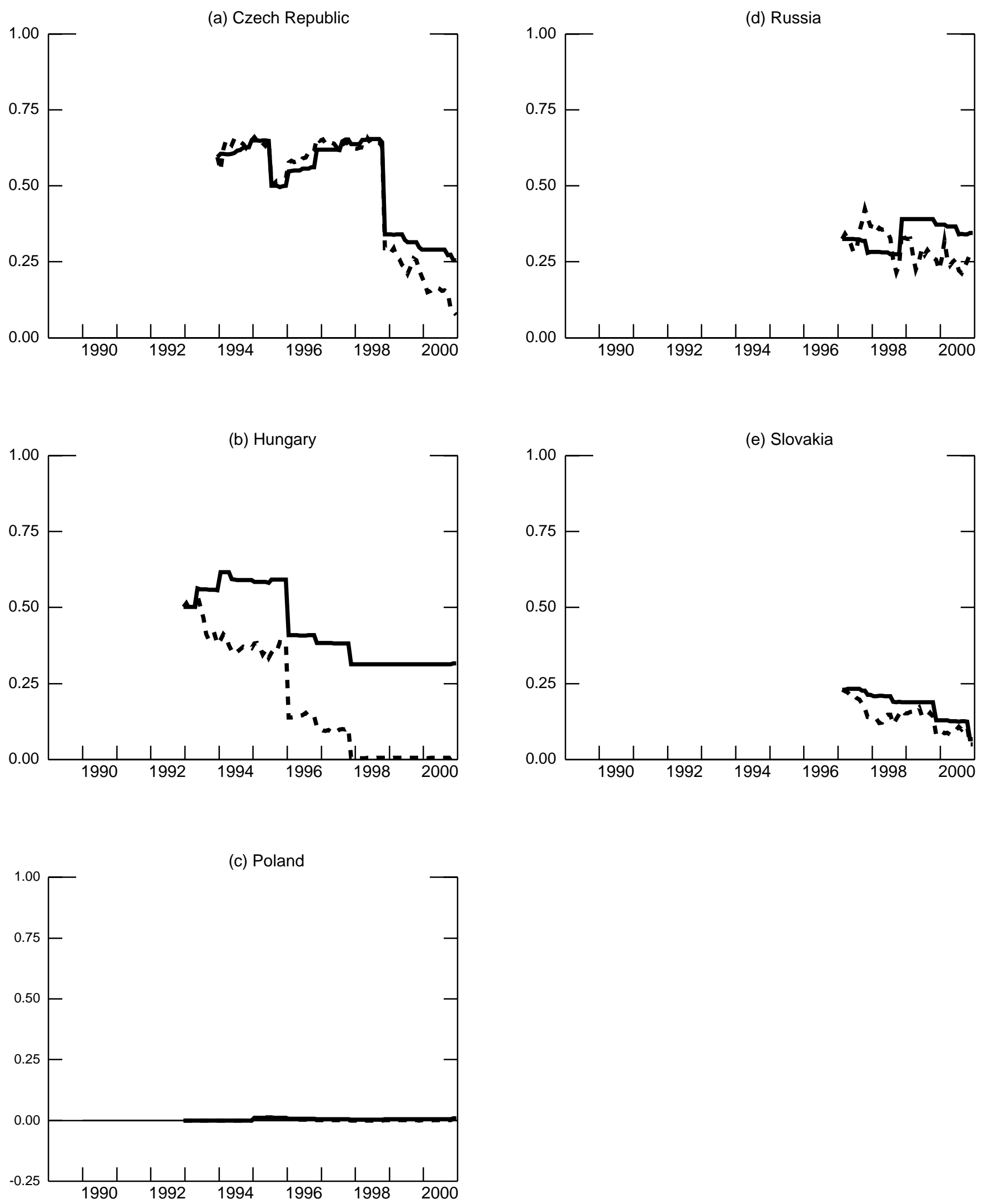
Figure 4. Foreign Ownership Restrictions, Emerging Europe. See Figure 1 for description. Bekaert and Harvey (2000a) liberalization dates are prior to 1989 for Greece and Portugal.
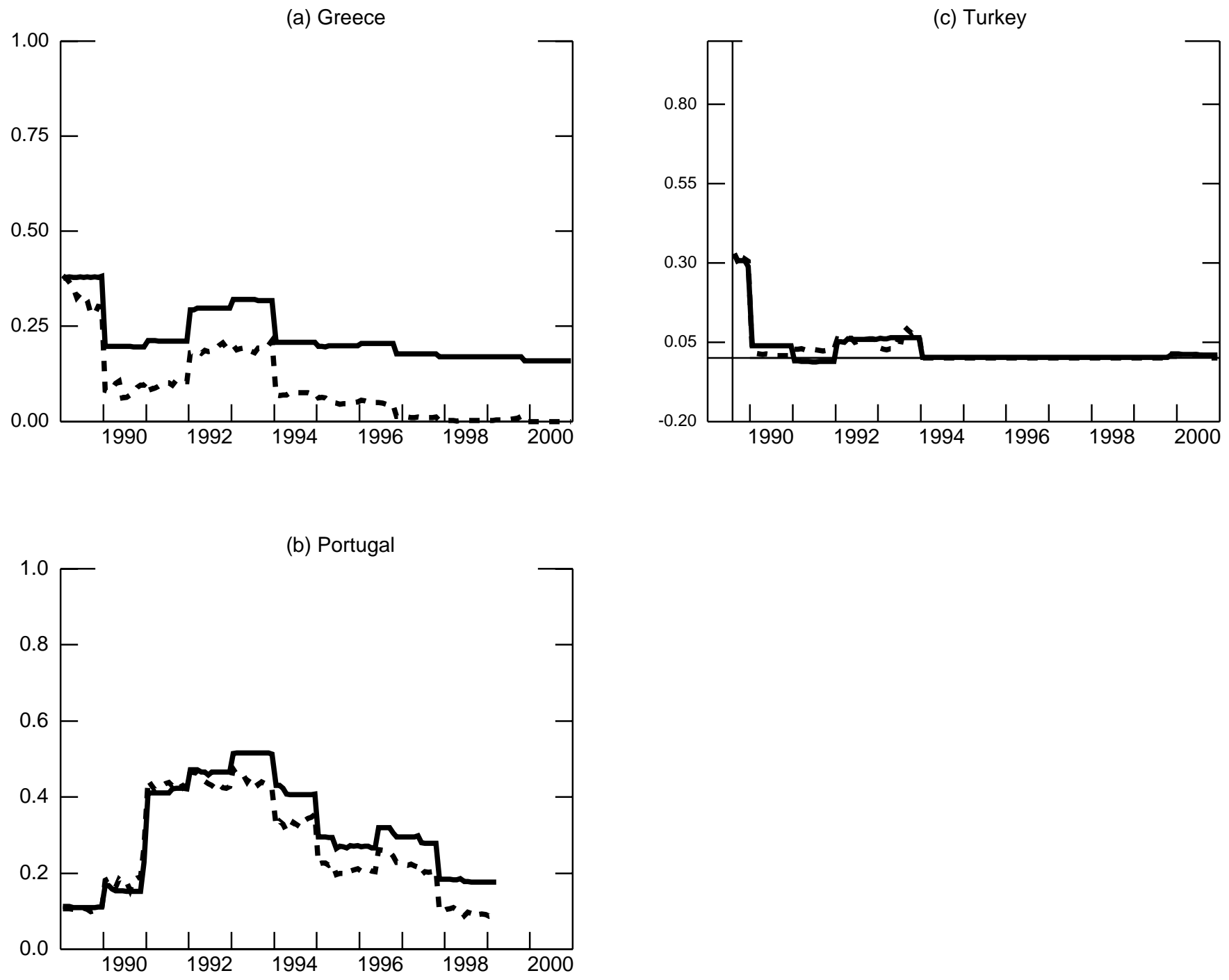
Figure 5. Foreign Ownership Restrictions, Middle East and Africa. See Figure 1 for description. Bekaert and Harvey (2000a) liberalization dates are not available for Morocco and South Africa.
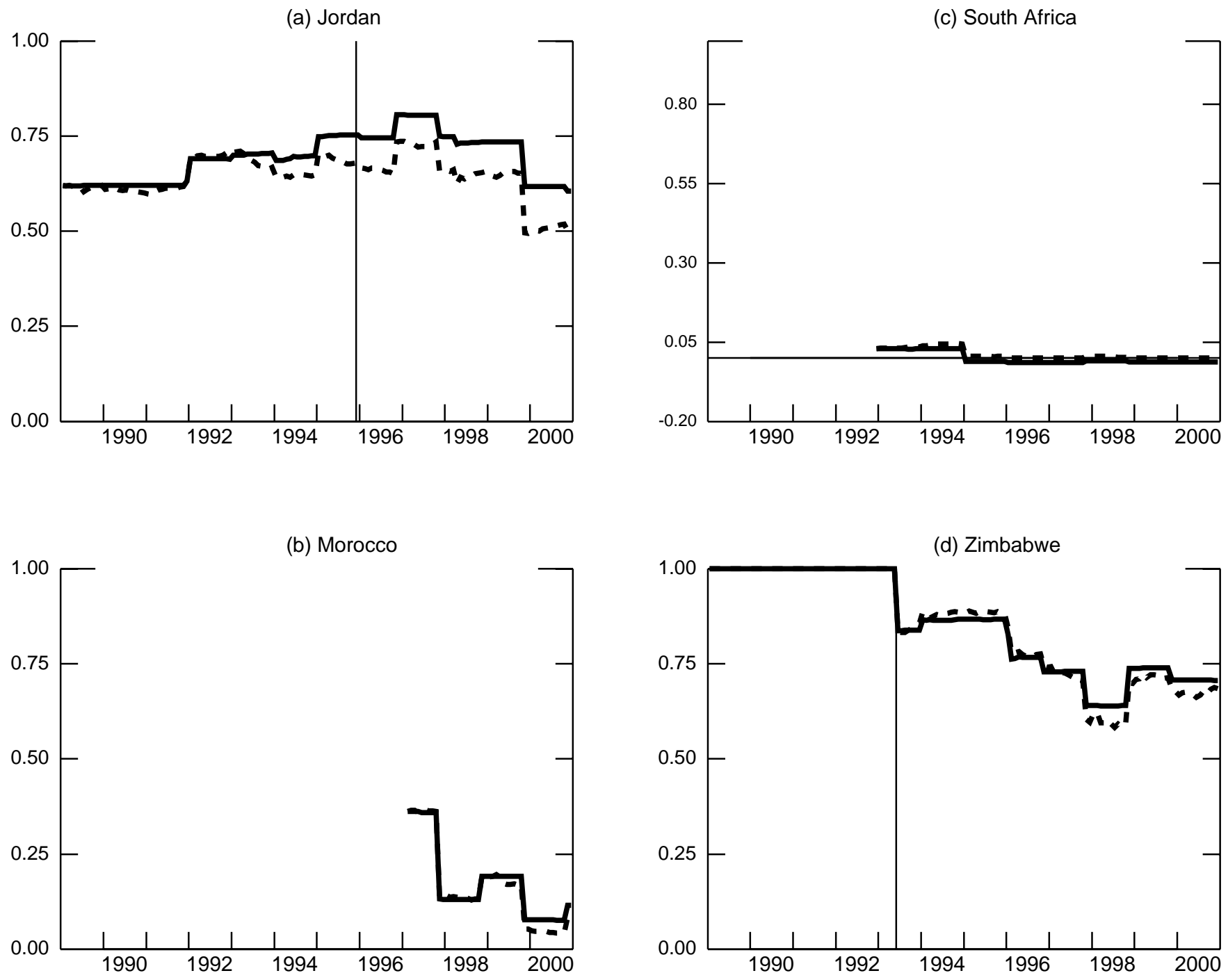
Figure 6. Liberalizations and the Cost of Capital. Foreign ownership restrictions (solid lines, left axis) are as in equation (1). Dividend yields (dashed lines, right axis) are the IFC's trailing 12-month dividends over price. The three periods in each graph correspond to the Bekaert and Harvey (2000a) pre-liberalization (from 36 to 7 months prior to the liberalization date), the during liberalization period (from 6 months prior to 3 months past), and the post-liberalization period (from 4 to 34 months after).
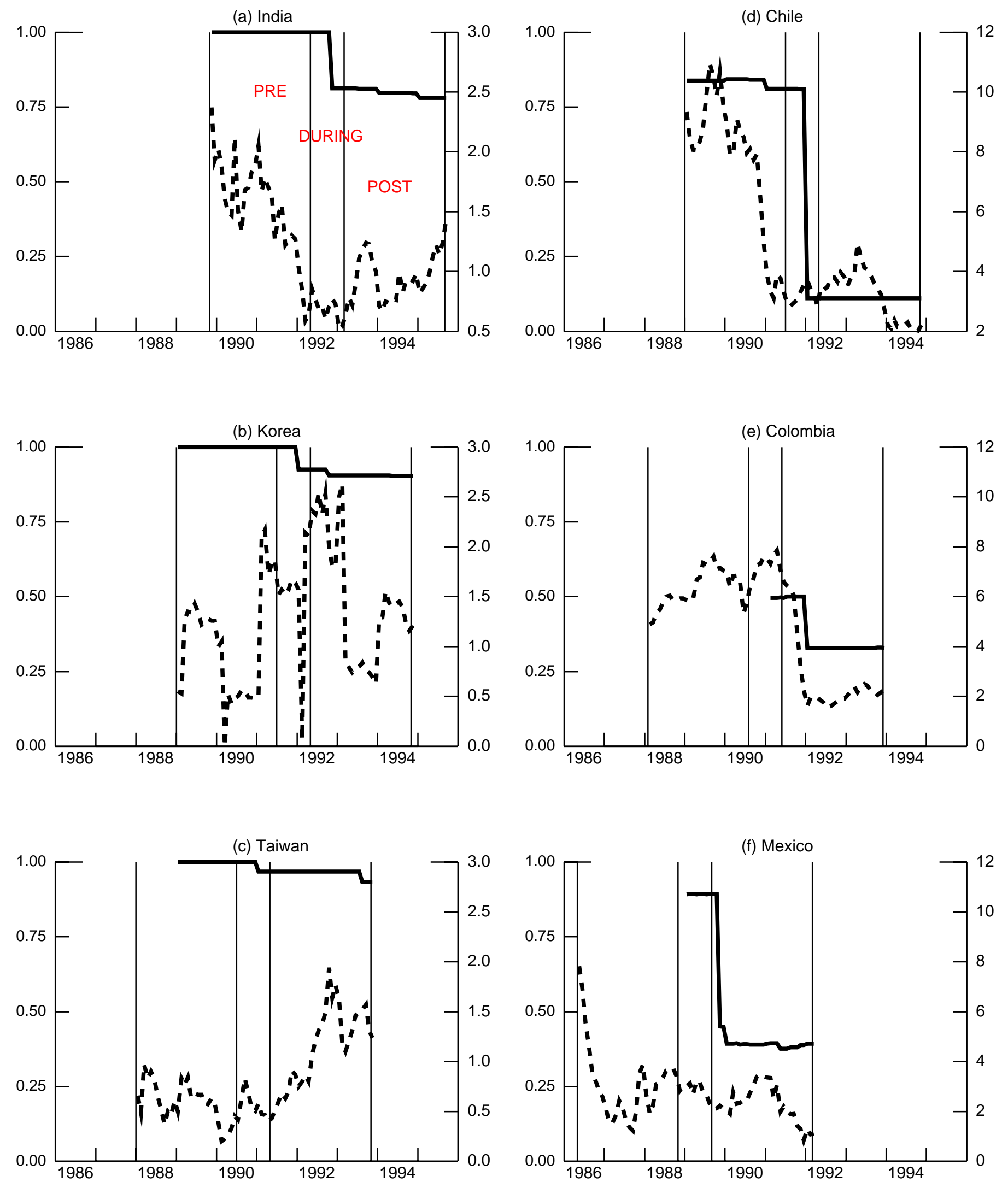